\title{
NOTES ON ORGANISMS SEROLOGICALLY RELATED TO S. ENTERITIDIS GÄRTNER. I. THE DUBLIN AND TOKYO TYPES OF SALMONELLA.
}

By P. BRUCE WHITE.

(From the Bacteriological Department, National Institute for Medical Research.)

PIONEER studies seemed to resolve the organisms of the Salmonella ${ }^{1}$ group into four types or groups sharply marked off from one another by their agglutinative reactions: S. typhosus, S. paratyphosus A, S. enteritidis Gärtner and a "paratyphoid B group." Later work has shown the heterogeneity of the old paratyphoid B group, which approximates to what we may now term the series of diphasic types; and further that S. typhosus and S. paratyphosus A, far from standing in serological isolation, display striking and peculiar relationships to certain members of this series: the flagellar antigen of the typhoid bacillus closely resembles that of the specific phase of the diphasic Stanley type, less closely that of the Bombay type; both in flagellar and somatic antigen $S$. paratyphosus A coincides with the specific phase of the diphasic Sendai type (typical paratyphus A bacillus of Aoki and Sakai, 1926).

There remains the case of $S$. enteritidis Gärtner and its immediate congeners. The existence of serological varieties within the Gärtner type has more than once been alleged. Hecht-Johansen (1923), for instance, separates from the original strains of Gärtner a number of enteritidis strains of human and rodent origin and including the well-known "rat viruses," "Ratin" and Daynsz bacillus. But, to judge by the representative cultures sent by Dr HechtJohansen, the differentiation of these sub-types was based only on the roughness and smoothness of the strains which they respectively included. An observation by Weil and Felix (1920) on differences in $\mathrm{O}$-antigen among Gärtner strains possibly related to the same type of contrast.

There are however a number of organisms, which, while in varied degree simulating S. enteritidis Gärtner in agglutinative properties, differ therefrom and from one another in the detail of their serology. First of these organisms to come within my personal experience was the Derby type (Peckham, 1923; White, 1925, 1926). This organism exhibits two well-developed flagellar factors which in an earlier paper (White, 1926) I have designated $Q$ and $R-Q$ being peculiar to the Derby type, $R$ being shared with $S$. enteritidis, which in turn possesses a differentiating flagellar factor, $P$; the somatic complex of the Derby type (II) differs from that of $S$. enteritidis (III), and has much

1 See Editor's note, p. 445. 
similarity to that of $S$. aertrycke and $S$. paratyphosus B. As a basis for further comparison, these two types may be given the relative antigenic formulae:

$\begin{array}{lcc} & \text { Enteritidis } & \text { Derby } \\ \text { Somatic } & \text { III } & \text { II } \\ \text { Flagellar } & R P & R Q\end{array}$

Almost simultaneously Pesch (1926) and Stuart and Krikorian (1926, with serological evidence furnished by Felix) reported $S$. enteritidis Gärtner as a cause of meningitis in children. In view of other similar records (Symmers and Wilson, 1909; Opitz, 1919) I examined the representative strains lodged at the National Collection of Type Cultures and found that while the Jerusalem strain of Stuart and Krikorian was, as Felix stated, true S. enteritidis Gärtner the strain of Pesch differed quite definitely from that organism in absorption tests. Later the organism of Pesch was identified with an aberrant enteritidis-like strain, sent by Dr J. W. Bigger and isolated in Dublin from a case of fatal fever supervening after a kidney operation; for this reason $I$ have named the organism the Dublin type.

In serology the Dublin type stands far closer to $S$. enteritidis than does the Derby type.

(1) Derby type serum is exhausted by $S$. enteritidis of agglutinins for the Dublin type; by the Dublin type of agglutinins for $S$. enteritidis: the Dublin type therefore holds, in common with $S$. enteritidis, the factor $R$.

(2) The Dublin type removes entirely the somatic agglutinins of enteritidis serum; S. enteritidis removes those of Dublin type serum : these types therefore show in common the somatic factor III.

(3) When enteritidis or Dublin type sera are saturated with the Derby type they still show well marked flagellar agglutinins for both types (enteritidis and Dublin): these types therefore possess in common, not only the flagellar factor $R$, but a portion $\left(P_{1}\right)$ of the factor $P$.

(4) When enteritidis serum is saturated with the Dublin type, or Dublin serum with $S$. enteritidis there remains in each case a definite residue of flagellar agglutinins for the homologous organism: this may be ascribed to the differential factors $P_{2}$ (enteritidis) and $P_{3}$ (Dublin).

Another and particularly interesting form-for which I adopt the title Tokyo type - is that described by Sakai (1925) as having caused food poisoning in Japan. Sakai showed that his organism could be resolved into two variant races, one agglutinable by $S$. enteritidis serum, the other by $S$. paratyphosus $\mathbf{B}$ serum. With a culture of the organism kindly sent by Prof. Aoki, I have confirmed Sakai's observation. The organism is a typical diphasic form: its somatic antigens are identical with those of S. enteritidis; the flagellar antigens of its specific phase coincide with those of the same organism and fail to react with the non-specific phase sera of other diphasic types; the non-specific phase, while reacting little or not at all to the flagellar agglutinins of Gärtner sera, is vigorously clumped by the non-specific phase anti-sera of the paratyphosus B, aertrycke Newport, and other diphasic types. The Tokyo type, therefore, 
stands in exactly the same relation to $S$. enteritidis, as that in which the Stanley and Sendai types stand to $S$. typhosus and S. paratyphosus A respectively: its discovery enormously strengthens the opinion I have elsewhere expressed (White, 1926) that the monophasic types (typhosus, paratyphosus A, enteritidis, etc.) are derivatives of a diphasic ancestry by suppression of the non-specific phase. It is perhaps a point of interest that two of the "missing links" should have been isolated in Japan.

The organisms which have been discussed may now be brought into comparison by use of the symbols which have been defined in the text.

\begin{tabular}{|c|c|c|c|c|}
\hline & Derby & Enteritidis & Dublin & Tokyo \\
\hline Somatic antigens & II* & III $\dagger$ & III & III \\
\hline Flagellar antigens: & & & & \\
\hline Specific phase & $\left\{\begin{array}{l}\Omega \\
Q\end{array}\right.$ & $\begin{array}{l}P_{1} \\
P_{1}\end{array}$ & $\begin{array}{l}n \\
P_{1}\end{array}$ & $\begin{array}{l}P_{1} \\
P_{1}\end{array}$ \\
\hline Non-specific phase & $(\mathrm{Nil})$ & (Nil) & (Nil) & $\begin{array}{l}\text { Broadly similar } \\
\text { to those of } B \text {. } \\
\text { paratyphosus } \mathrm{B} \\
\text { and other } \\
\text { diphasic types }\end{array}$ \\
\hline
\end{tabular}

With yet another enteritidis-like organism, the paratyphus $\mathrm{N} 2$ bacillus of Russian authors, Dr E. P. Hicks deals in a sister communication.

[Note. Some uniformity of nomenclature in papers of this number dealing with organisms of the Salmonella group has been introduced at the Editor's request in the interest of readers. It is however in no sense to be regarded as final.

Authoritative systems of nomenclature must await international sanction.-EDIToR.]

\section{REFERENCES.}

Aokr, K. and SaKaI (1926). Zentralbl. Bakt. Abt. I, Orig. 98, 9.

Hecht-Johansen, A. (1923). Classification of strains belonging to the Typhoid-Paratyphoid Group of Bacteria. Copenhagen.

OpITz, H. (1919). Monatschr. Kinderheilk. 15, 383.

Peckham, C. F. (1923). J. Hygiene, 22, 71.

Pescr, K. L. (1926). Zentralbl. Bakt. Abt. I, Orig. 98, 22.

SAKAI (1925). Ibid. 95, 152.

Stdart, G. and Krikorian, K. S. (1926). J. Hygiene, 25, 160.

Symmers, W. St C. and Wilson, W. J. (1909). Ibid. 13, 251.

WeIL, E. and Fet.IX, A. (1920). Zeitschr. f. Immunitätsf. 29, 69.

Weite, P. Bruce (1925). Sp. Rep. Ser., Med. Res. Coun. London, No. 91.

- (1926). Ibid. No. 103.

(MS. received for publication 13. x. 1929.-Ed.) 